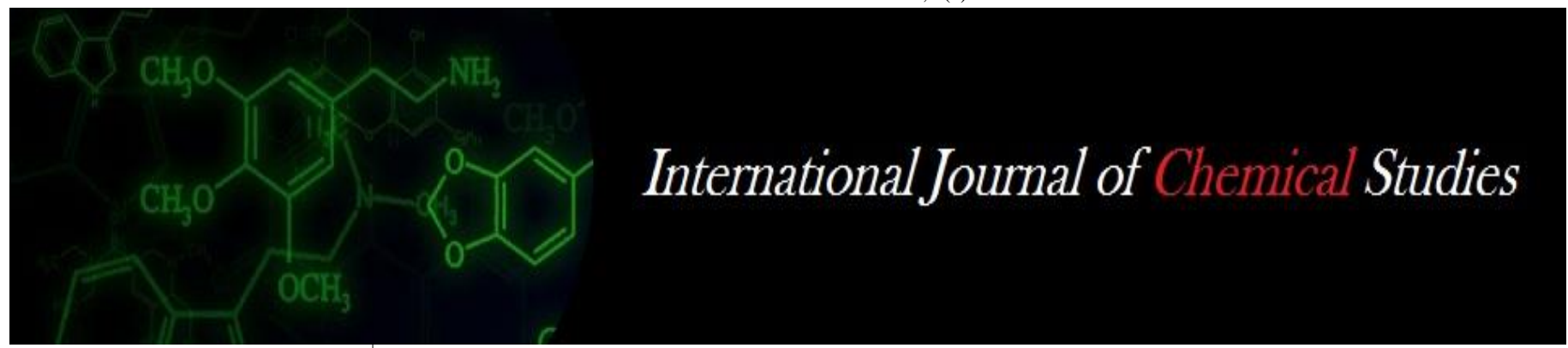

P-ISSN: 2349-8528

E-ISSN: 2321-4902

www.chemijournal.com

IJCS 2021; 9(1): 900-901

(C) 2021 IJCS

Received: 03-10-2020

Accepted: 07-11-2020

\section{Karan Kamboj}

M.Sc. Agronomy, School of

Agriculture, Lovely Professional

University, Phagwara, Punjab,

India

\section{J Himanshi}

B.Sc. Agriculture, School of Agriculture, Lovely professional University, Phagwara, Punjab, India
Corresponding Author: Karan Kamboj

M.Sc. Agronomy, School of Agriculture, Lovely Professional University, Phagwara, Punjab, India

\section{Effect of different levels of phosphorus on growth and fodder quality of cowpea A: Review}

\section{Karan Kamboj and J Himanshi}

DOI: $\underline{\text { https://doi.org/10.22271/chemi.2021.v9.i1m.11338 }}$

\begin{abstract}
Phosphorus is a significant nutrient for expanding efficiency of legumes crop. It is needed for plant development and root improvement. The three level of phosphorus $(40,60,80) \mathrm{kg}$ per ha as single super phosphate. In examination the impact of phosphorus level on development, number of turners, quality and yield of cowpea. The level of phosphorus $80 \mathrm{~kg}$ for each ha came about better development, nodulation and green forage yield and $40 \mathrm{~kg}$ for every ha has lower development, nodulation and green forage yield. The information with respect to the utilization of ideal portion supplements particularly phosphorus is not kidding concern. The writing about the development of growth cowpea (Vigna unguiculata $\mathrm{L}$.) comparable to phosphorus is reviewed in this paper.
\end{abstract}

Keywords: Growth, quality parameters, phosphorus

\section{Introduction}

Cowpea (Vigna unguiculata L.) is a large-seeded legume crop grown for its protein rich green pods, grains and stover by poor farmers under developed and developing countries. Cowpea commonly known as "Lobia" has a number of common names, including Crowder pea, black eyed pea, china pea etc. The beans are nutritious and provide complementary proteins to cereals. The seeds of cowpea comprise (20-24\%) protein, $63.3 \%$ carbohydrates and $1.9 \%$ fat. Worldwide, cowpea is cultivated on a total area over 11.2 million hectares with a total production of 3.2 million tonnes (Fatokun et al., 2012) ${ }^{[3]}$.

Fodder from cowpea is also highly valued for livestock. It can be grown as a relay inter-crop with cereals or other crops in mid, if maturing varieties were used for fodder. Cowpea plants are tolerant to drought, high temperature and soil acidity and their ability to fix atmospheric nitrogen contribute to their fast growth habit in tropical climates characterized by low rain fall, high temperature and soil with low fertility. Depending on the variety, cowpea performs well in agro ecological zones where rainfall ranges between $500 \mathrm{~mm}$ to $1200 \mathrm{~mm}$ per year (Madamba et al., 2006) ${ }^{[8]}$. The grains are major source of plant proteins and vitamins for man, feed for animals, young leaves and immature pods are eaten as vegetable and also source of money income (Sheahan, 2012) ${ }^{[14]}$.

Phosphorus has been reported to reinforce the formation of lateral, fibrous and adventitious roots, which play a very important role in N2 fixation, nutrient and water uptake (Rahman et al., 2008) ${ }^{[12]}$. It's one in every of the foremost important soil major nutrients for crop production especially legumes, it's rated the second to nitrogen in terms of its importance to crop performance (Halder and Panda, 2014) ${ }^{[4]}$. Therefore the requirement of $P$ for cowpea is quite higher than nitrogen in the form of single super phosphate (Nkaa et al., 2014) ${ }^{[10]}$. Supply and demand scenario of forage and roughages for 1995-2025 also provide the figure of actual deficit as per cent demand for green forage 696 million tons and dry roughages 143 million tons foe year 2015 which is based on Eleventh five year plan document, Government of India (Anonymous, 2007).

\section{Effect of phosphorus level}

Growth parameters: It was observed that, phosphorus is that Key Plant supplement associated with energy transfer inside the plant chemical reactions Rathore et al., (2015) ${ }^{[13]}$. The plant height, number of tillers, functional leaves per plant expanded fundamentally with increase in the leaves of phosphorus fertilization (Prasad. 2007) ${ }^{[11]}$. 
Bhagat et al., (2018) [1] reported that application of phosphorus up to $80 \mathrm{~kg} \mathrm{P}_{2} \mathrm{O}_{5}$ per ha resulted increase the plant height of Fodder Cowpea (6.59\%) as compare tov40 $\mathrm{kg} \mathrm{P}_{2} \mathrm{O}_{5}$ per ha. The stimulating effect of phosphorus on growth of crop might due to readily availability of applied phosphorus which promoted cell division, better root growth and increase intermodal length at higher level nutrient.

Kumar et al., (2012) ${ }^{[6]}$ detailed that utilization of phosphorus $80 \mathrm{~kg} \mathrm{P}_{2} \mathrm{O}_{5}$ ha resulted maximum number of nodules per plant and was significantly superior over 60 and $40 \mathrm{~kg} \mathrm{P}_{2} \mathrm{O}_{5}$ ha. They also increase the quality and yield. Meena and Chand (2014) ${ }^{[9]}$ detailed that the quantity of branches per plant in fodder cowpea increased with each progressive of phosphorus up to $60 \mathrm{~kg} \mathrm{P}_{2} \mathrm{O}_{5}$ ha. All growth parameters were significantly influenced due to phosphorus application which ultimately increased the root proliferation and also favoured the extensive exploitation of treated soil areas for nutrient and moisture while energy obtained from photosynthesis and metabolism of carbohydrates is stored in storage compound (ATP and ADP), which eventually reflected in vigorous vegetative growth. Phosphorus also promoted the development of roots thereby favouring the nitrogen fixation in legumes. This increased amount of nitrogen fixed might be utilized by the host plant for its own growth.

\section{Quality Parameters}

It was accounted for that, utilization of phosphorus delivered helpful impacts on crude protein content per cent and crude protein yield ( $q$ ha-1). The crude protein content was fundamentally expanded with increase within the degree of phosphorus application. The phosphorus application at $80 \mathrm{~kg}$ $\mathrm{P} 2 \mathrm{O} 5$ ha recorded higher crude protein content (18.38) and crude protein yield ( $8.46 \mathrm{q}$ ha) which was fundamentally above than all different degrees of phosphorus. The most minimal rough protein content was seen because of utilization of $40 \mathrm{~kg}$ P2O5 ha. While crude fiber yield, Acid detergent fiber, Neutral detergent fiber content didn't cross the degree of importance because of the utilization of levels of phosphorus. While the use of phosphorus at $80 \mathrm{~kg}$ P2O5 ha was discovered to be altogether higher in regard with ash content (11.73 percent), be that because it may, it was standard with at $60 \mathrm{~kg}$ P2O5 ha ash content (11.33) Bhagat et al., (2018) ${ }^{[1]}$.

\section{Effect of green forage yield}

The different level of phosphorus affected green forage yield essentially, that utilization of $80 \mathrm{~kg} \mathrm{P}_{2} \mathrm{O}_{5}$ ha recorded fundamentally higher green forage yield in terms of $\mathrm{q}$ ha-1. However, utilization of Phosphorus at $40 \mathrm{~kg} \mathrm{P}_{2} \mathrm{O}_{5}$ ha-1 recorded the altogether most reduced amount of green forage yield. The most extreme yield because of higher utilization of phosphorus, may be because of the joined impact of taller plants, more number of branches and more number of leaves per plant. Since the green forage yield is that the consolidated aftereffect of these three contributory characters, the yield within the current examination was expanded with expanded degree of phosphorus. Shekara et al. (2013) ${ }^{[15]}$ Kundu et al. $(2015)^{[7]}$

Economics: Jha et al., (2014) ${ }^{[5]}$ saw that the use of $80 \mathrm{~kg}$ $\mathrm{P}_{2} \mathrm{O}_{5}$ per ha recorded altogether most elevated Green forage yield (244.8 q/ha). Dry matter yield (45.6q /ha) and $40 \mathrm{~kg}$ $\mathrm{P}_{2} \mathrm{O}_{5}$ net return Rs 88895 and benefit cost ratio of 1.96

Dixit et al., (2014) ${ }^{[2]}$ the phosphorus application at $60 \mathrm{~kg}$ $\mathrm{P}_{2} \mathrm{O}_{5}$ produced greatest net return of Rs 3500 for each ha in fodeer cowpea.

\section{References}

1. Bhagat SB, Jadhao YS, Dahiphale AV, Mardane RD. Effect of different levels of phosphorus on growth, yield and economics of fodder cowpea (Vigna unguiculata L. Walp) varieties. IJCS 2018;6(6):376-378.

2. Dixit AK, Kumar S, Rai AK, Palsaniya DR. Productivity and profitability of fodder sorghum + cowpea- chickpea cropping system as influenced by organic manure, phosphorus and sulphur application in central India. Range Management \& Agroforestry 2014;35:66-72.

3. Fatokun CA, Boukar O, Muranaka S. Evaluation of cowpea (Vigna unguiculata (L.) Walp.) Germplasm lines for tolerance to drought. Plant Genetic Resources 2012;10(3):171.

4. Halder D, Panda RK. Determination of appropriate sowing date and phosphorus fertilization strategy for peanut in Eastern India. African Journal of Agricultural Research 2014;9(32):2475-2487.

5. Jha AK, Shrivastavaand A, Raghuvansi NS. Effect of different phosphorus levels on growth, fodder yield and economics of various cowpea genotypes under Kymore plateau and Satpura hills zone of Madhya Pradesh. Inter. J of Agric. Sci 2014;10(1):409-411.

6. Kumar A, Yadav PK, Yadav RK, Singh R, Yadav HK. Growth, biomass production and quality characters of cowpea as influenced by phosphorus and sulphur fertilization on loamy sands of semi-arid sub tropics. An Asian J of Soil Sci 2012;7(1):80-83.

7. Kundu CK, Das H, Roy DC, Bandopadhyay P, Bandyopadhyay S. Effect of different levels of phosphorus on yield and quality of fodder ricebean. Trends in Biosci 2015;8(1):64-67.

8. Madamba R, Grubben GJH, Asante IK, Akromah. Vigna unguiculata (L.) Walp record from Protabase. Brink, M. and Belay, G. (Eds). PROTA (Plant Resources of Tropical Africa), Wageningen, Netherlands 2006.

9. Meena LR, Chand R. Response of fodder cowpea to varying levels of nitrogen and phosphorus under rainfed condition of Rajasthan. The Indian Journal of Small Ruminants 2014;20:121-123.

10. Nkaa FA, Nwokeocha OW, Ihuoma O. Effects of Phosphorus fertilizer on growth and yield of cowpea (Vigna unguiculata (L.) Walp). IOSR Journal of Pharmacy and Biological Sciences (IOSR - JPBS). ISSN: 23197676, 2014;9(5):74-82.

11. Prasad R. Crop nutrition - Principle and Practices. 1st edition: 1-272. New Vishal Publications, New Delhi-India. Rajasree G, Pillai GR. Performance of fodder legumes under lime and phosphorus nutrition in summer rice fallows. Journal of tropical agriculture 2001-2007;39:6770.

12. Rahman MM, Bhuiyan MMH, Sutradhar GNC, Rahman MM, Paul AK. Effect of phosphorus, molybdenum and rhizobium inoculation on yield and yield attributes of mungbean. International Journal of Sustainable Crop Production 2008;3(6):26-33.

13. Rathore DK, Kumar R, Singh M, Meena VK, Kumar U, Gupta PS et al. Phosphorus and zinc fertilization in fodder cowpea: A review. Agricultural Reviews 2015;36(4):333338.

14. Sheahan CM. Plant guide for cowpea (Vigna unguiculata (L.) Walp). USDA- Natural Resources Conservation Services, Cape May, Plant Materials Center, Cape May, NJ 2012.

15. Shekara BG, Sowmyalatha BS, Bharatkumar C. Effect of phosphorus levels on forage yield of fodder cowpea. Environment \& Ecology 2013;31(2):561-563. 